\title{
Open Lip Schizencephaly: A Case Report.
}

\author{
Andrés F. Herrera $\mathrm{O}^{1}$, Héctor E. Ortiz $\mathrm{S}^{2 *}$. \\ 'Médico Cirujano, Universidad El Bosque. Bogotá-Colombia. \\ ${ }^{2}$ Médico Especialista en Pediatría, Fundación Universitaria de Ciencias de la Salud (FUCS). Bogotá-Colombia.
}

\begin{abstract}
Schizencephaly is an extremely rare congenital structural disorder presented in 1.54/100,000 births. In this article, we present one of the few cases of schizencephaly reported in Colombia, in which the linguistic barrier and the lack of resources made the differential diagnosis a challenge. The patient presented to the emergency department with focal impaired-awareness seizures associated with an inability to speak since birth. On physical examination, it was evident the loss of cephalic support, mental retardation, and leftsided hemiparesis for which a non-contrast brain computed tomography was performed showing findings that are in relation to open- lip schizencephaly (right frontoparietal brain cleft lined by gray matter which is connecting the subarachnoid space to the ventricular system, polymicrogyria and absence of septum pellucidum). Neurorehabilitation and antiseizure therapy were established with good outcomes. It is important to understand that nowadays does not exist any curative procedure, the mainstay of treatment is based on neuro- rehabilitation which should be initiated as soon as possible because it improves the cognitive and motor status of patients.
\end{abstract}

Palabras clave: Schizencephaly, Porencephaly, Seizures, Tomography X-Ray Computed

\section{RESUMEN}

\section{Esquizencefalia de labio abierto : Reporte de un Caso.}

La esquizencefalia es un trastorno estructural congénito extremadamente raro que se presenta en 1,54/100.000 nacimientos. En este artículo presentamos uno de los pocos casos de esquizencefalia reportados en Colombia, en el que la barrera lingüística y la falta de recursos hicieron del diagnóstico diferencial un desafío. El paciente acudió al servicio de urgencias por episodios de crisis epilépticas focales con conciencia alterada asociado a incapacidad para hablar desde el nacimiento. Al examen físico se evidenció pérdida del sostén cefálico, retraso mental y hemiparesia del lado izquierdo por lo que se realizó una tomografía computarizada de cerebro no contrastada que mostró hallazgos relacionados con esquizencefalia de labio abierto (hendidura fronto-parietal derecha delimitada por sustancia gris la cual está conectando el espacio subaracnoideo con el sistema ventricular, polimicrogiria y ausencia del septo pelúcido). Se estableció terapia con neuro-rehabilitación y anticonvulsivantes evidenciando una buena respuesta. Es importante entender que en la actualidad no existe ningún procedimiento curativo para la esquizencefalia, el pilar del tratamiento se basa en la neuro-rehabilitación la cual debe iniciarse lo antes posible debido a que mejora el estado cognitivo y motor de los pacientes.

Keywords: Esquizencefalia , Porencefalia ,Convulsiones, Tomografía Computarizada por Rayos X

*Autor de correspondencia:

Herrera Ortiz Andrés Felipe afherreraor@gmail.com

Como citar: Herrera Ortiz AF, Ortiz Sandoval HE. Open Lip Schizencephaly: A case Report. Revista Cuarzo 2020;26(2):27-29.

Recibido: 18 de octubre de 2020 Aceptado: 20 noviembre de 2020 Publicado: 30 de diciembre de 2020

DOI: https://doi.org/10.26752/cuarzo.v26.n2.510 


\section{INTRODUCTION}

$\mathrm{S}$ chizencephaly is an extremely rare congenital structural disorder of the brain that was initially described by Wadsworth and Yakolev (1). Its incidence is 1.54/100,000 births, with no gender predilection, schizencephaly is characterized by cleft formation lined by cortical gray matter $(2,3,4,5)$. According to morphological alterations, schizencephaly can be divided into:

1. Closed-lip or type 1 schizencephaly, in which the cortical cleft lined by gray matter does not connect with the ventricular system (3).

2. Open-lip or type 2 schizencephaly, in which the cortical cleft lined by gray matter connects with the ventricular system (3).

In most cases the septum pellucidum is absent and the gray matter along the cleft is polymicrogyric, moreover, the clefts can be unilateral or bilateral and can appear in any part of the brain, but the usual location is perisylvian $(2,3,4)$.

Below we are going to present one of the few cases of schizencephaly reported in Colombia, in which the linguistic barrier and the lack of resources made the differential diagnosis a challenge

\section{CASE REPORT}

A 5-year-old indigenous boy presented to the emergency department with an inability to speak since birth, associated with focal impaired-awareness seizures. The linguistic barrier was challenging due to the patient's lack of knowledge of Spanish, given that they proceed from the "Embera Katío" indigenous community. On physical examination, it was evident the loss of cephalic support, mental retardation, and left-sided hemiparesis, the hearing ability was normal. The mother gave birth at age of 19 with no history of gestational controls and no similar cases in the family. The patient has not received any treatment during his life.

Routine blood tests were performed including hemogram, electrolytes, and liver function enzymes within normal parameters, for which a non-contrast brain computed tomography (CT) was obtained, showing a right frontoparietal brain cleft lined by gray matter, which is connecting the subarachnoid space to the ventricular system, also the absence of septum pellucidum and the presence of polymicrogyria are seen. These findings are in relation to unilateral right open-lip schizencephaly (Figure 1).

Once the diagnosis of open-lip schizencephaly was established, the patient received neuro-rehabilitation and antiseizure treatment with phenobarbital, presenting adequate control of the seizures on day 4, for which discharge was given with a neuropediatric control appointment.

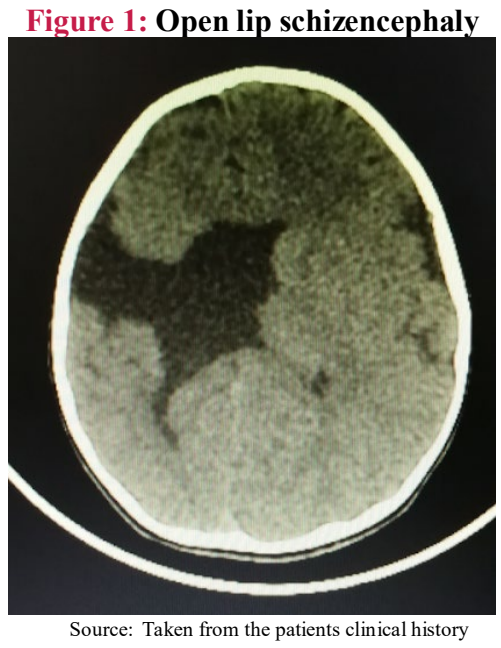

III. DISCUSSION

The pathophysiology of schizencephaly is not well established, but it is believed that it is caused by an alteration of neuronal migration. The literature supports three theories: 1 . An ischemic episode occurring at the 7th or 8th week of gestation, 2. Genetic cause, 3 . cytomegalovirus congenital infections $(4,5)$

The absence of septum pellucidum presented in our patient suggests a heterozygous EMX2 gene mutation, although this condition has been related to other genes such as SIX 3 and SHH which are also associated with neuroblastic migration $(5,6,7,8)$. Schizencephaly type 2 is the most common, the clinical presentation depends on the size and location of the cleft, but it is frequently manifested by refractory epilepsy, mental retardation, hemiparesis (in cases of unilateral schizencephaly), and quadriparesis (in cases of bilateral schizencephaly) $(9,10)$. When type 1 schizencephaly is presented the disease course is milder, usually being diagnosed incidentally (9).

The pathognomonic imaging finding of schizencephaly is the identification of gray matter lining the brain cleft, for that reason magnetic resonance imaging (MRI) is the diagnostic method of choice due to the excellent gray matter differentiation, that can easily distinguish between schizencephaly and others fluid-associated central nervous system abnormalities such as porencephalic cysts, in which the gray matter is not lining the brain cleft (Figure 2) (11).

Figure 2: Differences between schizencephaly and porencephalic cyst.

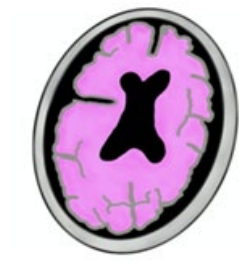

Closed-lip Schizencephaly

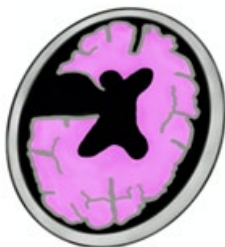

Open-lip Schizencephaly Source: Elaborated by the authors

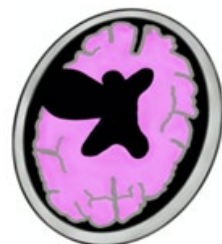

Porencephalic cyst 
CT can adequately diagnose schizencephaly (especially the open-lip type) but due to the limited capacity to distinguish the gray matter, it is not used as the ideal diagnostic method. The principal role of CT in the diagnosis of schizencephaly is when MRI is not available $(9,11)$. In our institution, we do not have MRI, for that reason the diagnosis was made using $\mathrm{CT}$.

Prenatal diagnosis of open-lip schizencephaly can be performed with ultrasonography beginning at 24th weeks of gestation, allowing counseling of the parents to prepare themselves for the inevitable clinical consequences of the defect when pregnancy termination is not an option $(12,13)$.

The treatment is focused on neuro-rehabilitation and seizure control. Approximately $30 \%$ of patients develop hydrocephalus (almost exclusively in type 2 schizencephaly), for which a ventriculoperitoneal shunt can be performed. In the open-lip variety, the prognosis is worse due to chronic infections and respiratory problems that may lead to early death (14).

\section{CONCLUSIONS}

An interdisciplinary approach is crucial in patients with schizencephaly, it is important to understand that nowadays does not exist any curative procedure. The mainstay of the treatment is based on neuro-rehabilitation which should be initiated as soon as possible because it improves the cognitive and motor status of patients, and in some cases allows a complete and normal development.

Conflicts of Interest: The authors do not declare any conflicts of interest.

\section{REFERENCES}

1. Denis D, Chateil JF, Brun M, Brissaud O, Lacombe D, Fontan D, Flurin V, Pedespan J. Schizencephaly : Clinical imaging features in 30 infantile cases. Brain Dev 2000 Dec; 22(8)475-83. doi: 10.1016/s0387-7604(00)00173-x

2. Griffiths PD. Schizencephaly revisited. Neuroradiology. 2018 Sep;60(9):945-960. doi: 10.1007/s00234-018-2056-7

3. Stopa J, Kucharska-Miąsik I, Dziurzyńska-Białek E, Kostkiewicz A, Solińska A, Zając-Mnich M, Guz W, Samojedny A. Diagnostic imaging and problems of schizencephaly. Pol J Radiol. 2014 Nov 30;79:444-9. doi: 10.12659/PJR.890540

4. Rege SV, Patil H. Bilateral giant open-lip schizencephaly: A rare case report. J Pediatr Neurosci. 2016;11(2):128-30. doi: $10.4103 / 1817-1745.187638$

5. Valentina Ortega Rivera, Laura Margarita Arango Bedoya ,Laura María Pineda Jiménez, Juan Camilo SuárezEscudero. Integridad cognitiva y motora-sensorial en un niño con esquizencefalia de labio abierto unilateral derecho: Reporte de caso. Acta neurol colomb.2018; 34 (1):59-63. https://doi.org/10.22379/24224022180
6. Dies KA, Bodell A, Hisama FM, Guo CY, Barry B, Chang BS, et al. Schizencephaly: association with young maternal age, alcohol use, and lack of prenatal care. J Child Neurol. 2013;28(2):198-203.

http://dx.doi.org/10.1177/0883073812467850

7. Hehr U, Pineda-Alvarez DE, Uyanik G, Hu P, Zhou N, Hehr A, et al. Heterozygous mutations in SIX3 and SHH are associated with schizencephaly and further expand the clinical spectrum of holoprosencephaly. Hum Genet. 2010;127(5):555-61. http://dx.doi.org/10.1007/s00439-010$0797-4$

8. Tietjen I, Bodell A, Apse K, Mendonza AM, Chang BS, Shaw GM, et al. Comprehensive EMX2 genotyping of a large schizencephaly case series.Am J Med Genet A. 2007; 143 (12):1313-1316. https://doi.org/10.1002/ajmg.a.31767

9. Halabuda A, Klasa L, Kwiatkowski S, Wyrobek L, Milczarek O, Gergont A. Schizencephaly-diagnostics and clinical dilemmas. Childs Nerv Syst. 2015 ;31(4):551-6. doi: $10.1007 / \mathrm{s} 00381-015-2638-1$

10. Timmanna Giraddi et al. Closed Lip Schizencephaly: A Case report . International Journal of Biomedical and Advance Research 2015; 6(12): 868-869. DOI: 10.7439/ijbar

11. Naresh Bansal,Suvinay Saxena, Pratik Panasara, Ankur Shah, Dhaval Mistry. Open lip schizencephaly with septooptic dysplasia. 2018. doi:10.1594/EURORAD/CASE. 14168

12. Huertas Tacchino Erasmo, Aquino Dionisio Rosario, Armas De los Rios Diana, Esteban Blas Alvaro, Ventura Laveriano Walter, Castillo Urquiaga Walter. Diagnóstico prenatal de esquizencefalia. Reporte de caso y revisión de la literatura. Rev. peru. ginecol. obstet. 2020;66( 1 ): 89-93. http://dx.doi.org/10.31403/rpgo.v66i2238

13. Karen Y. Oh,Anne M. Kennedy. Fetal schizencephaly: Preand Postnatal Imaging with a Review of the Clinical Manifestations. Radiographics. 2005 25(3):647-57 https://doi.org/10.1148/rg.253045103

14. Varma PV, Bhat YR, Bhatt S. Unilateral open-lip schizencephaly: A rare cause of infantile hemiparesis. J Pediatr Neurosci 2012 ;7(3):234-5. doi: 10.4103/18171745.106490 